\title{
ROLE OF STATINS IN CONTROLLING COUGH AND IMPROVING LUNG FUNCTION AND EXERCISE CAPACITY IN BRONCHIECTASIS PATIENTS.
}

\footnotetext{
1. MBBS, FCPS

Assistant Professor Pulmonology

Teaching Hospital DG Khan.

2. MBBS, FCPS

Medical Officer Pulmonology Nishtar Medical University.

3. MBBS, FCPS

Medical Officer Pulmonology Nishtar Medical University.

4. MBBS, FCPS

Medical Officer Pulmonology Ch. Pervaiz Ellahi Institute of Cardiology Multan.

5. FCPS

Assistant Professor Pulmonology Ch. Pervaiz Ellahi Institute of Cardiology Multan.
}

Correspondence Address:

Dr. Masood Alam

Department of Pulmonology Ch. Pervaiz Ellahi Institute of

Cardiology Multan.

dr.masood174@gmail.com

Article received on:

13/02/2019

Accepted for publication:

$11 / 10 / 2019$
Abdul Rauf ${ }^{1}$, Syed Sarmad Ali Naqvi², Muhammad Imran Sharif ${ }^{3}$, Masood Alam ${ }^{4}$, Muhammad Imran Shehzad ${ }^{5}$

ABSTRACT... Objectives: To investigate the role of high dose atorvastatin in controlling cough improving lung function and exercise capacity in patients with bronchiectasis. Study Design: Cross Sectional Study. Setting: Respiratory unit of Nishtar hospital Multan. Period: January 2016 to September 2018. Material \& Methods: Total 58 patients were enrolled having clinically significant bronchiectasis having productive cough and were clinically stable. Consecutive sampling was done and patients were divided into two groups by lottery method. Group A received high dose atorvastatin $80 \mathrm{mg}$ once daily for 6 months and group $B$ received placebo for 6 months. Patients in both groups received other standard medical treatment. Results: The mean FEV1, FVC, FEV2/FVC, WBC, CRP and LCQ score unit for the statin group was $2.44 \pm 0.73 \mathrm{~L}, 3.36 \pm 0.84 \mathrm{~L}, 67.42 \pm 6.21,6.94 \pm 1.89 \times 10^{9}$ cells per $\mathrm{L}, 6.35 \pm 1.21 \mathrm{mg} / \mathrm{L}$ and $15.40 \pm 3.62$ respectively. While, the mean FEV1, FVC, FEV2/FVC, WBC, CRP and LCQ score unit for the placebo group was $2.10 \pm 0.86 \mathrm{~L}, 2.82 \pm 1.11 \mathrm{~L}, 67.31 \pm 3.09,6.53 \pm 2.55 \times 10^{9}$ cells per $L, 9.21 \pm 6.39 \mathrm{mg} / \mathrm{L}$ and $13.56 \pm 2.73$ respectively. The difference was statistically significant for FVC $(p=0.038)$, CRP $(p=0.022)$ and LCQ score units $(p=0.033)$. The mean FEV ${ }_{1}$ FVC, $\mathrm{FEV}_{1} / \mathrm{FVC}$, improvement in 6MWT and improvement in LCQ scores units for the statin group was $0.0517 \pm 0.31 \mathrm{~L},-0.0172 \pm 0.32 \mathrm{~L}, 0.000 \pm 0.20,-0.1354 \pm 0.48 \mathrm{~m}$ and $2.2 \pm 1.08$ units respectively. Improvement in LCQ score $>1.3$ units was observed in $n=7(24.1 \%)$ patients. While, the mean $\mathrm{FEV}_{1}, \mathrm{FVC}, \mathrm{FEV}_{1} / \mathrm{FVC}$, improvement in 6MWT and improvement in LCQ scores units for the placebo group was $0.061 \pm 0.24 \mathrm{~L},-0.0483 \pm 0.30 \mathrm{~L}, 0.179 \pm 0.29,0.001 \pm 0.47 \mathrm{~m}$ and $-0.7214 \pm 0.25$ units respectively. Improvement in LCQ score $>1.3$ units was observed in $n=12(41.4 \%)$ patients. The difference was statistically significant for improvement in LCQ score units $(p=0.000)$. Conclusion: Statins can be used in controlling the cough in patients with bronchiectasis. But its role in improving lung function test and exercise capacity need further research and investigation.

Key words: $\quad$ Atorvastatin, Bronchiectasis, Lung Function, Cough, Statins.

Article Citation: Abdul Rauf, Syed Sarmad Ali Naqvi, Muhammad Imran Sharif, Masood Alam, Muhammad Imran Shehzad. Role of statins in controlling cough and improving lung function and exercise capacity in bronchiectasis patients. Professional Med J 2020; 27(5):885-890.

DOI: 10.29309/TPMJ/2020.27.05.3283

\section{INTRODUCTION}

Bronchiectasis chronic respiratory disease, caused by permanent dilatation of bronchioles and is characterized by recurrent chest infection productive cough and shortness of breath. Bronchiectasis is not a rare disease but however it is regarded as orphan disease because of Limited research and trials. In this era of CT scan the exact incidence of bronchiectasis is not available. There is poor understanding about pathogenesis of bronchiectasis hot but histopathology shows increase neutrophilic inflammation. Almost two thirds patients of bronchiectasis are chronically infected. ${ }^{1}$ Increased level of neutrophilic inflammation in the airways cause bronchial wall damage and enhance chances of bacterial infection. ${ }^{2} \mathrm{C}$ reactive protein which is systemic inflammatory marker is increased in bronchiectasis and directly related to severity of disease and inversely related to quality of life and lung function in stable bronchiectasis. ${ }^{3}$

Evidence based data is limited in treatment of this disease. Currently Physiotherapy of chest and long term use of antibiotics is approach in which disorder. Continuous use of antibiotics raised 
many concerns because it causes side effects Health Care associated infection and resistance. Because of these concerns research is underway to investigate the role of anti-inflammatory agents in bronchiectasis.

Pleiotropic effects of statins such as decreasing the inflammation and enhancing the adoptive and emanate immune system. ${ }^{4,5}$ Statins decrease recruitment of neutrophils in human and animal experimental system in sterile inflammation. ${ }^{6,7}$ Use of high dose statins in treatment of Pulmonary infection with staphylococcus in murine models caused increased production of DNA traps extracellularly by engulfing within the lungs and increased protection against infection dissemination. . $^{8,9}$ Use of high dose simvastatin for long period has dose dependent protection against pneumonia. ${ }^{10}$

Anti-inflammatory effect of statins had been investigated in other respiratory diseases. But there is limited delta about use of statins in bronchiectasis. In this study $v$ have investigated the role of statins in improving quality of life and functional status of bronchiectasis patients. This research will encourage more curiosity about use of stations in bronchiectasis and will encourage more investigation in this topic.

\section{MATERIAL \& METHODS}

This is a cross sectional study conducted from January 2016 to September 2018. In this investigation total 58 patients were enrolled from outdoor of respiratory unit of Nishtar hospital Multan. Patients were having clinically significant bronchiectasis having productive cough and were clinically stable. Patient's disease were confirmed by HRCT chest and having history of one or more acute exacerbation of bronchiectasis were included from 15 to 65 years old age. Consecutive sampling was done and patients were divided into two groups by lottery method. Group-A received high dose atorvastatin $80 \mathrm{mg}$ once daily for 6 months and group B received placebo for 6 months. Patients in both groups received other standard medical treatment. Consent was taken from these patients and approval was taken of this research from ethical committee. Patients having history of COPD, uncontrolled asthma, heavy smoking history, cystic fibrosis, diffuse parenchymal lung disease, decompensated liver disease and allergic pulmonary aspergillosis were excluded from study. Patients having chronic infection with pseudomonas aeruginosa and emphysematous changes on HRCT chest were also excluded. Sample size calculated by reference study in which cough improved in $40 \%$ patients using atorvastatin as compared to placebo in which $17 \%$ patient's improved. ${ }^{11}$

Patients selected in this study were examined and analyzed at baseline after enrolling in this research. Spirometry was done and FEV1, FVC and FEV1/FVC were documented pre bronchodilation. Functional status was checked also by 6 minute walk test and recording distance covered at baseline. Both spirometry and 6-minute walk distance were also checked after 6 months of treatment in both groups. Patient's detailed history of asthma, smoking, occupation was also taken. Body mass index were documented and was auscultated. Vitals were recorded at baseline and blood sample was also drawn to check white blood cells, blood sugar and $\mathrm{c}$ reactive proteins.

Cough was assessed at baseline by self-filling Leicester Cough Questionnaire (LCQ). This questioner has total score of 3 to 21 in which lower score indicates severe cough. This assessment was also done after 6 months. Minimum improvement of 1.3 units in this score was taken as significant improvement in cough.

Data was analyzed by SPSS volume 22 . Qualitative variables OD data like gender, age, smoking status were statistically calculated by percentage and chi square test was applied to check the significance. Quantitative variables like LCQ score, FEV1, FVC and its ratio and 6 minute walk test were calculated in mean and standard deviation and significance checked with t test. $\mathrm{P}$ value of less than .005 was considered significant.

\section{RESULTS}

Fifty-eight patients were included in this study, both genders. We study two groups i.e. statin and placebo respectively. The mean age and BMI statin 
group was $52.41 \pm 3.71$ years and $26.06 \pm 4.04 \mathrm{~kg} /$ $\mathrm{m}^{2}$ respectively. Gender distribution observed as $\mathrm{n}=15(51.7 \%)$ males and $\mathrm{n}=14(48.3 \%)$ females. $\mathrm{n}=25 \quad(86.2 \%)$ were smokers. Asthma and diabetes mellitus was noted as $n=11$ (37.9\%) and $n=8(27.6 \%)$ respectively. While, the mean age and BMI statin group was $55.82 \pm 1.93$ years and $28.83 \pm 2.65 \mathrm{~kg} / \mathrm{m}^{2}$ respectively. Gender distribution observed as $\mathrm{n}=18(62.1 \%)$ males and $n=11(37.9 \%)$ females. $n=21(72.4 \%)$ were smokers. Asthma and diabetes mellitus was noted as $n=13(44.8 \%)$ and $n=5(17.2 \%)$ respectively. The difference was statistically for age $(p=0.000)$ and BMI $(p=0.003)$. (Table-l).

The mean FEV1, FVC, FEV2/FVC, WBC, CRP and LCQ score unit for the statin group was $2.44 \pm 0.73$ L, $3.36 \pm 0.84 \mathrm{~L}, \quad 67.42 \pm 6.21,6.94 \pm 1.89 \times 10^{9}$ cells per $\mathrm{L}, 6.35 \pm 1.21 \mathrm{mg} / \mathrm{L}$ and $15.40 \pm 3.62$ respectively. While, the mean FEV1, FVC, FEV2/ FVC, WBC, CRP and LCQ score unit for the placebo group was $2.10 \pm 0.86 \mathrm{~L}, 2.82 \pm 1.11$ $\mathrm{L}, \quad 67.31 \pm 3.09,6.53 \pm 2.55 \times 10^{9}$ cells per $\mathrm{L}$, $9.21 \pm 6.39 \mathrm{mg} / \mathrm{L}$ and $13.56 \pm 2.73$ respectively. The difference was statistically significant for FVC $(p=0.038)$, CRP $(p=0.022)$ and LCQ score units $(p=0.033)$. (Table-II).

The mean $\mathrm{FEV}_{1}$, FVC, $\mathrm{FEV}_{1} / \mathrm{FVC}$, improvement in 6MWT and improvement in LCQ scores units for the statin group was $0.0517 \pm 0.31 \mathrm{~L},-0.0172 \pm 0.32 \mathrm{~L}$, $0.000 \pm 0.20,-0.1354 \pm 0.48 \mathrm{~m}$ and $2.2 \pm 1.08$ units respectively. Improvement in LCQ score $>1.3$ units was observed in $n=7(24.1 \%)$ patients. While, the mean $\mathrm{FEV}_{1}, \mathrm{FVC}, \mathrm{FEV}_{1} / \mathrm{FVC}$, improvement in 6MWT and improvement in LCQ scores units for the placebo group was $0.061 \pm 0.24 \mathrm{~L}$, $-0.0483 \pm 0.30 \mathrm{~L}, 0.179 \pm 0.29,0.001 \pm 0.47 \mathrm{~m}$ and $-0.7214 \pm 0.25$ units respectively. Improvement in LCQ score $>1.3$ units was observed in $n=12$ (41.4\%) patients. The difference was statistically significant for improvement in LCQ score units $(p=0.000)$. (Table-III).

\begin{tabular}{|c|c|c|c|}
\hline Variable & $\begin{array}{l}\text { Statin } \\
\text { Group } \\
n=29\end{array}$ & $\begin{array}{c}\text { Placebo } \\
\text { Group } \\
n=29\end{array}$ & P-Value \\
\hline Age (years) & $52.41 \pm 3.71$ & $55.82 \pm 1.93$ & 0.000 \\
\hline $\mathrm{BMI}\left(\mathrm{kg} / \mathrm{m}^{2}\right)$ & $26.06 \pm 4.04$ & $28.83 \pm 2.65$ & 0.003 \\
\hline \multicolumn{4}{|c|}{ Gender } \\
\hline Male & $\begin{array}{c}n=15 \\
(51.7 \%)\end{array}$ & $\begin{array}{c}n=18 \\
(62.1 \%)\end{array}$ & \multirow{2}{*}{0.291} \\
\hline Female & $\begin{array}{c}n=14 \\
(48.3 \%)\end{array}$ & $\begin{array}{c}n=11 \\
(37.9 \%)\end{array}$ & \\
\hline \multicolumn{4}{|c|}{ Smoking } \\
\hline Never & $\begin{array}{c}n=4 \\
(13.8 \%)\end{array}$ & $\begin{array}{c}n=8 \\
(27.6 \%)\end{array}$ & \multirow{2}{*}{0.195} \\
\hline Former & $\begin{array}{c}n=25 \\
(86.2 \%)\end{array}$ & $\begin{array}{c}n=21 \\
(72.4 \%)\end{array}$ & \\
\hline Asthma & $\begin{array}{c}n=11 \\
(37.9 \%)\end{array}$ & $\begin{array}{c}n=13 \\
(44.8 \%)\end{array}$ & 0.594 \\
\hline Diabetes & $\begin{array}{c}n=8 \\
(27.6 \%)\end{array}$ & $\begin{array}{c}n=5 \\
(17.2 \%)\end{array}$ & 0.345 \\
\hline
\end{tabular}

Table-I. Baseline characteristics among the groups.

$\mathrm{BMI}=$ body mass index

\begin{tabular}{|c|c|c|c|}
\hline Variable & $\begin{array}{l}\text { Statin } \\
\text { Group } \\
\mathrm{n}=29\end{array}$ & $\begin{array}{c}\text { Placebo } \\
\text { Group } \\
n=29\end{array}$ & P-Value \\
\hline FEV1(L) & $2.44 \pm 0.73$ & $2.10 \pm 0.86$ & 0.102 \\
\hline FVC (L) & $3.36 \pm 0.84$ & $2.82 \pm 1.11$ & 0.038 \\
\hline FEV2/FVC (\%) & $67.42 \pm 6.21$ & $67.31 \pm 3.09$ & 0.932 \\
\hline $\begin{array}{l}\text { WBC } \times 10^{9} \text { cells } \\
\text { per } L\end{array}$ & $6.94 \pm 1.89$ & $6.53 \pm 2.55$ & 0.490 \\
\hline CRP mg/L & $6.35 \pm 1.21$ & $9.21 \pm 6.39$ & 0.022 \\
\hline LCQ score unit & $15.40 \pm 3.62$ & $13.56 \pm 2.73$ & 0.033 \\
\hline \multicolumn{4}{|c|}{ Table-II } \\
\hline Variable & $\begin{array}{l}\text { Statin Group } \\
\qquad n=29\end{array}$ & $\begin{array}{c}\text { Placebo } \\
\text { Group } \\
n=29\end{array}$ & $\begin{array}{c}\text { P- } \\
\text { Value }\end{array}$ \\
\hline FEV1(L) & $0.0517 \pm 0.31$ & $0.061 \pm 0.24$ & 0.398 \\
\hline $\mathrm{FVC}(\mathrm{L})$ & $-0.0172 \pm 0.32$ & $-0.0483 \pm 0.30$ & 0.706 \\
\hline FEV1/FVC & $0.000 \pm 0.20$ & $0.179 \pm 0.29$ & 0.783 \\
\hline $\begin{array}{l}\text { Improvement } \\
\text { in } 6 \text { MWDT } \\
(\mathrm{m})\end{array}$ & $-0.1354 \pm 0.48$ & $0.001 \pm 0.47$ & 0.279 \\
\hline $\begin{array}{l}\text { Improvement } \\
\text { in LCQ score } \\
\text { units }\end{array}$ & $2.2 \pm 1.08$ & $-0.7214 \pm 0.25$ & 0.000 \\
\hline $\begin{array}{l}\text { Improvement } \\
\text { in LCQ score } \\
>1.3 \text { units }\end{array}$ & $\mathrm{n}=7(24.1 \%)$ & $n=12(41.4 \%)$ & 0.162 \\
\hline
\end{tabular}




\section{DISCUSSION}

Results of study showed that patients in statin group using high dose statin improved in over all cough measured by LCQ score. This improvement was also statistically significant from baseline. While in control group improvement in cough was not significant. While in both groups that is case and control improvement in FEV1, FVC and ration of these was not significant. And functional capacity measured by 6-minute walk distance was also not improved in both groups.

Bronchiectatic lung secretions are result of chemotactic activity of leukotriene $\mathrm{B}_{4}$ and interleukin $8 .^{12}$ statins have immunomodulatory effect and it has been studied in many chronic lung diseases. In study done by Wang et al. showed that statins cause fewer exacerbations in chronic obstructive pulmonary disease. ${ }^{13}$ Statin also decrease risk of death by $39 \%$ in chronic obstructive lung disease.${ }^{14}$ In study done by Li et al. showed that use of statin after surgery of lung transplantation improved maintenance of graftlung function, improved survival and delay the onset of bronchiolitis obliterans. ${ }^{15}$

There is increased airway inflammation in bronchiectasis due to neutrophil persistence for longer period. ${ }^{16}$ There is regulation of inflammation by programmed cell death or apoptosis. ${ }^{17}$ Apoptosis is a major process of neutrophils death and it life can be extended and functional activity of neutrophils can be improved by cytokines such as interferon gamma, granulocyte-macrophages stimulating factor, granulocyte colony stimulating factor and interleukin. ${ }^{2,17}$

Neutrophilic apoptosis showed that it stimulated inflammation resolution and fast recovery in vivo model in pneumococcal infection. ${ }^{18}$ Statins caused decreased amount of BCL2 which is an anti-apoptotic protein in cancer cell lines in human as well in murine non cancer cell lines. ${ }^{19}$ Statins also enhanced efferocytosis in vivo, that has important role in disease in which this process is impaired. ${ }^{20}$

Statins role in enhancing neutrophilic apoptosis in airways or process by which it increases apoptosis of neutrophils in patient's sputum with bronchiectasis should be fully investigated. It is of great therapeutic potential by which activated neutrophils are switched of and neutrophils underwent apoptosis in bronchiectasis by enhancing resolution of inflammation.

Statins also has antithrombotic effects and causes reduction in endothelial dysfunction in sepsis in animal models that improves outcome. No adverse effects of statins documented in viable bacterial load sputum.

Investigations and research until now suggest the treatment with statins in bronchiectasis for longer period and macrolides for antiinflammatory approach. Randomized controlled trials in bronchiectasis investigated role of macrolides. ${ }^{21,22,23,24}$ Results of these trials showed that macrolides in full dose or low dose for 6 to 24 months caused decrease in frequency of exacerbation.

In this study results showed that statins improved cough in patients who used high dose of atorvastatin as compared to placebo group. But lung function test and exercise capacity were not improved in both groups.

Limited sample size and no long term follow up of the patients were limitation of this study.

\section{CONCLUSION}

Statins can be used in controlling the cough in patients with bronchiectasis. But its role in improving lung function test and exercise capacity need further research and investigation.

\section{Copyright $@ 11$ Oct, 2019.}

\section{REFERENCES}

1. Weycker D, Hansen GL, Seifer FD. Prevalence and incidence of noncystic fibrosis bronchiectasis among US adults in 2013. Chron Respir Dis. 2017 Nov; 14(4):377-384.

2. Dente FL, Bilotta M, Bartoli ML, Bacci E, Cianchetti S, Latorre $\mathrm{M}$, et al. Neutrophilic bronchial inflammation correlates with clinical and functional findings in patients with noncystic fibrosis bronchiectasis. Mediators Inflamm. 2015; 2015:642503. 
3. Taylor SL, Rogers GB, Chen AC, Burr LD, McGuckin MA, Serisier DJ. Matrix metalloproteinase vary with airway microbiota composition and lung function in non-cystic fibrosis bronchiectasis. Ann Am Thorac Soc. 2015 May; 12(5):701-7.

4. Oesterle A, Laufs U, Liao JK. Pleiotropic effects of statins on the cardiovascular system. Circ Res. 2017 Jan $6 ; 120(1): 229-43$.

5. Funderburg NT, Jiang Y, Debanne SM, Labbato D, Juchnowski S, Ferrari B, et al. Rosuvastatin reduces vascular inflammation and $T$ cell and monocyte activation in HIV-infected subjects on antiretroviral therapy. J Acquir Immune Defic Syndr. 2015 Apr 1; 68(4):396-404.

6. Hiraiwa K, Miller S, Ngan DA, Vasilescu DM, Hackett TL, Kinose D, et al. Statins reduce the burden of ambient particulate matter and inflammatory cells within the lung tissues of smokers with and without COPD. Eur Respir J. 2017 Jan 3; 49(1).

7. Jang HR, Rabb H. Immune cells in experimental acute kidney injury. Nat Rev Nephrol. 2015 Feb; 11(2):88101.

8. Robb CT, Regan KH, Dorward DA, Rossi AG. Key mechanisms governing resolution of lung inflammation. Semin Immunopathol. 2016 Jul; 38(4):425-48.

9. Cheng L. Relevance of neutrophils and neutrophil extracellular traps in bronchiolitis obliterans syndrome of patients receiving stem cell therapy (Doctoral dissertation, University of Toronto (Canada).

10. Batais MA, Khan AR, Abdulhak AA. The use of statins and risk of community-acquired pneumonia. Curr Infect Dis Rep. 2017 Aug; 19(8):26.

11. Mandal P, Chalmers JD, Graham C, Harley C, Sidhu MK, Doherty $\mathrm{C}$, et al. Atorvastatin as a stable treatment in bronchiectasis: A randomised controlled trial. Lancet Respir Med. 2014 Jun; 2(6):455-63.

12. MC Pasteur, D Bilton, AT Hill British. Thoracic society guideline for non-CF bronchiectasis. Thorax, 65 (suppl 1) (2010), pp. 1-58.

13. MT Wang, YW Lo, CL Tsai, et al. Statin use and risk of COPD exacerbation requiring hospitalization. Am J Med, 126 (2013), pp. 598-606
14. L Lahousse, DW Loth, GF Joos, et al. Statins, systemic inflammation and risk of death in COPD: The rotterdam study. Pulm Pharmacol Ther, 26 (2013), pp. 212-217.

15. Y Li, J Gottlieb, D Ma, et al. Graft-protective effects of the HMG-CoA reductase inhibitor pravastatin after lung transplantation: A propensity score analysis with 23 years of follow-up. Transplantation, 92 (2011), pp. 486-492.

16. AP Watt, V Brown, J Courtney, et al. Neutrophil apoptosis, proinflammatory mediators and cell counts in bronchiectasis. Thorax. 2004 Mar; 59(3):2316.

17. IM Tleyjeh, T Kashour, FA Hakim, et al. Statins for the prevention and treatment of infections. A systematic review and meta-analysis. Arch Intern Med, 169 (2009), pp. 1658-1667.

18. U Koedel, M Klein, HW P fister. Modulation of brain injury as a target of adjunctive therapy in bacterial meningitis. Curr Infect Dis Rep. 2010 Jul; 12(4):266-73.

19. WG Wood, U Igbavboa, WE Muller, GP Eckert Statins, $\mathrm{Bcl}-2$, and apoptosis: Cell death or cell protection?

20. MW Merx, EA Liehn, J Graf, et al. Statin treatment after onset of sepsis in a murine model improves survival. Circ 112 (2005), pp. 117-124.

21. C Wong, L Jayaram, N Karalus, et al. Azithromycin for prevention of exacerbations in non-cystic fibrosis bronchiectasis (EMBRACE): A randomised, doubleblind, placebo-controlled trial. Lancet, 380 (2012), pp. 660-667.

22. DJ Serisier, ML Martin, MA McGuckin, et al. Effect of long-term, low-dose erythromycin on pulmonary exacerbations among patients with non-cystic fibrosis bronchiectasis: The BLESS randomized controlled trial. JAMA, 309 (2013), pp. 1260-1267.

23. J Altenburg, CS de Graaff, Y Stienstra, et al. Effect of azithromycin maintenance treatment on infectious exacerbations among patients with non-cystic fibrosis bronchiectasis: The BAT randomized controlled trial. JAMA, 309 (2013), pp. 1251-1259.

24. PC Valery, PS Morris, CA Byrnes, et al. Long-term azithromycin for Indigenous children with noncystic-fibrosis bronchiectasis or chronic suppurative lung disease (Bronchiectasis Intervention Study): A multicentre, double-blind, randomised controlled trial. Lancet Respir Med, 1 (2013), pp. 610-620. 


\begin{tabular}{|c|c|c|c|}
\hline \multicolumn{4}{|c|}{ AUTHORSHIP AND CONTRIBUTION DECLARATION } \\
\hline Sr. \# & Author(s) Full Name & Contribution to the paper & Author(s) Signature \\
\hline 1 & Abdul Rauf & Conception \& Study design. & \\
\hline 2 & Syed Sarmad Ali Naqvi & Data collection \& literature & \\
\hline 3 & Muhammad Imran Sharif & $\begin{array}{l}\text { Manuscript writing \& Data } \\
\text { analysis. }\end{array}$ & \\
\hline 4 & Masood Alam & $\begin{array}{l}\text { Data collection \& Manuscript } \\
\text { writing. }\end{array}$ & \\
\hline 5 & M. Imran Shehzad & Final approval \& Proof reading. & \\
\hline
\end{tabular}

